 \\ z Filologii Polskiej i Słowiańskiej
}

DOI: $10.11649 /$ sfps.2014.014

\author{
Wiesław Babik \\ (Instytut Informacji Naukowej i Bibliotekoznawstwa \\ Uniwersytetu Jagiellońskiego, Kraków)
}

\section{Słowa kluczowe, tagi..., i co dalej?}

\section{Wprowadzenie}

Przedmiot artykułu stanowią słowa kluczowe oraz ich nowsza odmiana, zwana tagami. Zostaną zaprezentowane realizowane przez nie funkcje oraz tworzone przez nie struktury. Prezentacja słów kluczowych i tagów ma na celu wykazanie, że nie są to grupy słownictwa homonimiczne pod względem zarówno strukturalnym, jak i funkcjonalnym. Wymienione typy jednostek leksykalnych zostaną zaprezentowane z punktu widzenia teorii języków informacyjno-wyszukiwawczych oraz teorii wyszukiwania informacji. Zostaną także przedstawione - z uwzględnieniem dalszych losów tych jednostek leksykalnych oraz języków, których są elementami - folksonomie, ontologie i mapy myśli jako nowe rodzaje struktur słów kluczowych i tagów.

Słowa kluczowe i tagi to w praktyce swoistego rodzaju ,języki”, które podobnie jak język naturalny - podlegają ciągłym zmianom. Stąd potrzeba ciągłego monitorowania zmian słownictwa danego języka naturalnego. Artykuł

This is an Open Access article distributed under the terms of the Creative Commons Attribution 3.0 PL License (creativecommons.org/licenses/by/3.0/pl/), which permits redistribution, commercial and non-commercial, provided that the article is properly cited. (C) The Author(s) 2014.

Publisher: Institute of Slavic Studies, PAS \& The Slavic Foundation

[Wydawca: Instytut Slawistyki PAN \& Fundacja Slawistyczna] 
stanowi głos w dyskusji na temat tworzonych w Instytucie Slawistyki PAN w Warszawie słowników słów kluczowych, stanowiących element języka systemu slawistycznej informacji bibliograficznej.

Traktując bardzo ogólnie język słów kluczowych, zajmujemy się zwykle jego odmianą standardową, tj. klasycznym językiem słów kluczowych, którym jest język swobodnych słów kluczowych, a więc nie dostrzegamy istnienia innych równorzędnych niestandardowych odmian tego języka wykorzystywanych w komunikacji naukowej. Powinniśmy mieć jednak świadomość, że przyjęty model definicyjny języka słów kluczowych jest tworem abstrakcyjnym wygenerowanym na bazie wielu istniejących konkretnych języków słów kluczowych (Smiraglia, 2013).

W rozpatrywaniu słów kluczowych za niezbędną należy zatem uznać świadomość współistnienia różnych odmian języków słów kluczowych, w tym świadomość, że klasyczny język słów kluczowych jest językiem naturalnym (Babik, 2010), gdyż znaczna część języków słów kluczowych to języki paranaturalne.

Źródłem słów kluczowych jest przede wszystkim terminologia. Terminologia to - w interpretacji językoznawczej - pewien podzbiór w leksyce danego języka ogólnonarodowego, charakteryzujący się stosunkowo wąskim zakresem zastosowania i rozpowszechnienia oraz ograniczonym stopniem rozumienia (ograniczonym do specjalistów) (Bojar, 2002). Terminy odzwierciedlają system pojęć danej dziedziny wiedzy lub działalności zawodowej.

Charakterystycznymi cechami słów kluczowych jako jednostek leksykalnych są: sieciowość (tu szczególnym przypadkiem jest system); mozaikowość; naturalność (jednostki leksykalne języka naturalnego, tendencja do fraz kluczowych). Skoro to język naturalny, to słowa kluczowe są „żywe”, a więc zmienne, zróżnicowane i mają swój cykl życia.

W systemie informacyjno-wyszukiwawczym słowa kluczowe pełnią następujące funkcje:

- funkcja identyfikacyjna (określanie czegoś);

- funkcja nominatywna (nazywanie czegoś);

- funkcja dystynktywna (rozróżnianie czegoś).

Formy zarówno słów kluczowych, jak i tagów, bywają zróżnicowane - od prostych słów kluczowych po frazy kluczowe. Przykład fraz kluczowych może stanowić następujący zestaw wyrażeń: „SŁOWA KLUCZOWE: Nauki o książce, bibliotece i informacji (naukowej). Ewolucja dyscypliny. Wielojęzyczne nazewnictwo dyscypliny. Tendencje współczesne. Bibliografia. Księgoznawstwo. 
Księgoznawstwo historyczne. Księgoznawstwo funkcjonalne. Bibliotekoznawstwo. Informacyjne i komunikacyjne modele księgoznawstwa. Kultura książki. Kategorie badawcze" (Migoń, 2008, s. 14).

Języki słów kluczowych nie stanowią jednolitej (homogenicznej) grupy języków, a tym bardziej jednego języka. To klasa języków informacyjno-wyszukiwawczych bardzo zróżnicowana pod względem zarówno strukturalnym, jak i funkcjonalnym (Babik, 2010). Charakterystyczne cechy języków słów kluczowych to: różnorodność struktur semantycznych i gramatycznych; różnorodność funkcji; leksyka oparta na terminologii, ale nie wyłącznie; zróżnicowanie tożsamości tych języków (języki sztuczne, ale i naturalne).

W projektowaniu i budowie języków informacyjno-wyszukiwawczych można wyróżnić dwa podejścia:

- podejście taksonomiczne (gdy język tworzą specjaliści);

- podejście folksonomiczne (gdy język tworzą zwykli użytkownicy).

W efekcie powstają wyróżniane w piśmiennictwie na temat języków słów kluczowych:

- języki o słownictwie swobodnym;

- języki o słownictwie kontrolowanym;

- języki o słownictwie częściowo kontrolowanym (Babik, 2010).

Biorąc pod uwagę genezę tych języków, trzeba mieć świadomość, że języki słów kluczowych podlegają ciągłej ewolucji - od unitermów, poprzez słowa kluczowe, po tagi, metatagi i folksonomie.

Języki słów kluczowych i języki tagów jako typ języka informacyjno-wyszukiwawczego pełnią w systemie informacyjno-wyszukiwawczym funkcję metainformacyjną (opisową) i/lub funkcję wyszukiwawczą.

\section{Język słów kluczowych a język naturalny}

Słowa kluczowe jako wyrażenia języka naturalnego różni od pozostałych wyrażeń języka naturalnego to, że są używane w specjalnej funkcji, a mianowicie w funkcji metainformacyjnej, w jej odmianie dokumentacyjnej.

Z językoznawczego punktu widzenia można wyróżnić dwie perspektywy badawcze słów kluczowych: denotacyjną i konotacyjną. Denotacyjna perspektywa słów kluczowych zakłada, że granice między zakresami słów kluczowych 
są nieostre. Słowa kluczowe to rodzaj etykiet językowych. Konotacyjna perspektywa słów kluczowych opiera się na założeniu, że w słowach kluczowych najważniejsza jest treść. Słowo kluczowe to informacja/metainformacja, która odsyła do wiedzy zakodowanej w umyśle odbiorcy.

Słowa kluczowe są nie tylko stosunkowo łatwym narzędziem językowym identyfikacji i wymiany informacji, lecz także ogromną bazą danych i nieocenionym źródłem informacji i wiedzy o zagadnieniach będących przedmiotem tej wymiany. Słowa kluczowe okazują się użyteczne/przydatne w tagowaniu (tagi), semantyzacji (ontologie), mapowaniu (mapy myśli).

\section{Problemy}

W obecnie funkcjonujących systemach wyszukiwania informacji, w których używa się słów kluczowych, bardziej chodzi o wyzyskiwanie denotacji niż konotacji. Słowa kluczowe mają zakresy nieostre i rozmyte. Jak już sygnalizowałem, nie ma też jednego języka słów kluczowych. Istnieje wiele różnych języków słów kluczowych, w tym „podobny” do folksonomii język autorskich słów kluczowych.

Słowa kluczowe i/lub tagi mogą funkcjonować w następujących strukturach: folksonomie, ontologie, mapy myśli.

Według definicji w polskiej wikipedii folksonomia to praktyka kategoryzacji treści z wykorzystaniem dowolnie dobranych słów kluczowych (Folksonomia, b.d.). Folksonomie ${ }^{1}$ to opisywanie stron WWW, danych, informacji, dokumentów i innych obiektów informacyjnych przez ich użytkowników za pomocą tagów (Zaremba, 2011), stąd tagowanie. Wszelkie definicje tagowania sprowadzają się do stwierdzenia, że tagowanie polega na nadawaniu słów kluczowych obiektom dostępnym w zasobach sieciowych (Górska, 2012). Tag to wyraz (lub rzadziej fraza językowa) oznaczający wybrany segment informacji, to dowolnie dobierane słowa kluczowe używane w języku naturalnym. Cel tagowania stanowi opis i porządkowanie zasobów informacyjnych w Internecie w taki sposób, aby ich użytkownicy mogli je wyszukiwać intuicyjnie, łatwo i szybko (Stępień, 2010). Tagowanie - jak pisze Jadwiga Woźniak-Kasperek:

1 Twórcą pojęcia folksonomia był Thomas Vander Wal, który po raz pierwszy użył tej nazwy w 2004 roku podczas dyskusji nad sposobami opisu zasobów internetowych. 
„jest w pewnym sensie powrotem do klasyki indeksowania manualnego za pomocą swobodnych słów kluczowych, z tym że tymi, którzy to robią, nie są specjaliści w zakresie indeksowania, ale użytkownicy Internetu. Indeksowanie to odbywa się za pomocą tagów - słów kluczowych, jakkolwiek różnie rozumianych. Tagi opisują obiekt w kategoriach uznanych przez jego odbiorców za relewantne pożądane i pożyteczne" (Woźniak-Kasperek, 2011, ss. 192-193).

Siłą tagowania i folksonomii jest ilość tworząca nową jakość, która nie zawsze jest jednak cenna. Folksonomie to języki indeksowania, które powstają w trakcie rozproszonego opisywania zasobów Internetu przez liczne osoby tagujące (Furner, 2010). Folksonomie mogą przybierać różne formy - od liniowego spisu tagów, klastrów lub hybryd tagowo-fasetowych, po najpopularniejszy sposób prezentacji, jakim jest mająca cechy sieci chmura tagów. To nowy sposób prezentacji i wizualizacji treści zwany także chmurą znaczników. W istocie to zestaw znaczników będących aktywnymi linkami do stron WWW prezentowanych z wykorzystaniem zróżnicowania wielkości czcionki (czasami również intensywności kolorów) odpowiadającej ważności strony (Roszkowski, b.d.).

Tagi to swobodne słowa kluczowe nadawane przez użytkowników w Internecie, zaś tagowanie to nadawanie dokumentom w Internecie swobodnych słów kluczowych przez użytkowników. W tagowaniu wszystkie wpisy, bez względu na kategorię, mogą więc być opatrzone słowami i/lub frazami kluczowymi, stanowiącymi zamknięty katalog w celu uniknięcia niekorzystnych dla procesów indeksacyjnych i wyszukiwawczych wariantyzacji i synonimizacji słów kluczowych. Wykaz wszelkich stosowanych tagów może być dostępny na stronie serwisu pod odpowiednim linkiem (np. Wszystkie Tagi), znajdującym się zaraz pod ruchomą chmurą tagów. Jeśli jest to wykaz wszystkich tagów, to tym samym katalog ten stanowić może wykaz słownictwa kontrolowanego, używanego w danym serwisie (Noruzi, 2006).

W celu zapewnienia wysokiej jakości treści danego serwisu informacyjnego wszystkie wpisy przed ich zamieszczeniem mogą być moderowane, adiustowane oraz formatowane na potrzeby prezencyjne serwisu. Tagowanie wpisów często pozostaje w gestii redakcji serwisu. Autorzy wpisów są jednak zobowiązani do opatrywania swoich prac słowami kluczowymi. Słowa (tagi) spoza istniejącego ich katalogu są zwykle traktowane jako nowe propozycje i uwzględniane pod warunkiem akceptacji ich siły opisowej. W przypadku artykułów naukowych każda zmiana powinna być autoryzowana przez twórcę artykułu. 
Folksonomie to nieeksperckie [niehierarchiczne] potoczne struktury kategoryzacji treści z użyciem dowolnych słów kluczowych, często stosowane w portalach społecznościowych i w środowisku biblioteki (Czapik, Gruszka \& Tadeusiewicz, 2011, s. 99), podczas gdy chmura tagów to układ (głównie graficzny) znaczników/słów kluczowych, którym zwykle odpowiadają linki do odpowiednich części serwisów informacyjnych, ilustrujący obecność i wagę lub popularność danego znacznika (Rys. 1).

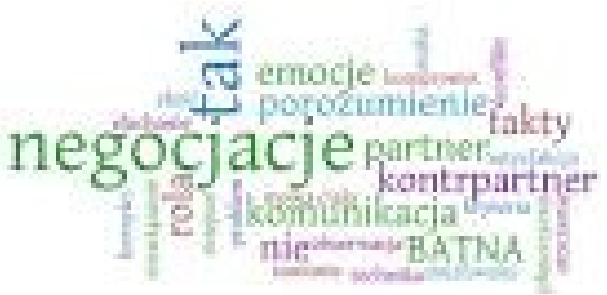

Rys. 1. Przykład chmury tagów

Źródło: http://praktykatrenera.pl/efektowna-wizualizacja-pojec-chmura-tagow (Efektowna wizualizacja pojęć - chmura tagów, b.d.)

Ontologie to zbiory słownictwa (m.in. słów kluczowych), których znaczenie jest określane poprzez sieć relacji semantycznych istniejących między elementami tworzącymi ten zbiór, pozwalające na odpowiednią interpretację poszczególnych jego elementów (Rys. 2).

\section{WIKIFEUU SEMTENGES}

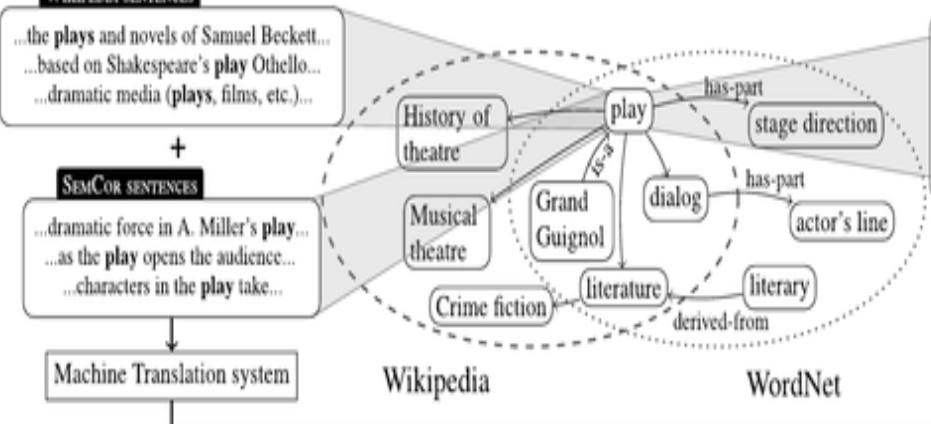

\section{Bans.Srasn}

play $_{\text {ss, }}$ drama $_{2 s}$, obra Bühnenwerk ot, obra . Theaterstück, opera teatrale $_{\pi}$, dramma ${ }_{\pi}$, pièce de théâtre

Rys. 2. Przykład ontologii

Źródło: http://en.wikipedia.org/wiki/BabelNet (BabelNet, b.d.) 
Mapy myśli (ang. think maps) to wielowymiarowe układy pojęć (na poziomie ich wyrażania m.in. przez słowa kluczowe), które odwzorowują naturalne procesy myślowe przebiegające w umyśle człowieka. Zwykle jest to drzewiasty układ tematów szczegółowych składających się na strukturę danego bardziej złożonego zagadnienia, rozwiązywanego problemu. Przeważnie to dynamiczne struktury informacji oparte na powiązaniach pomiędzy poszczególnymi jej elementami (Rys. 3).

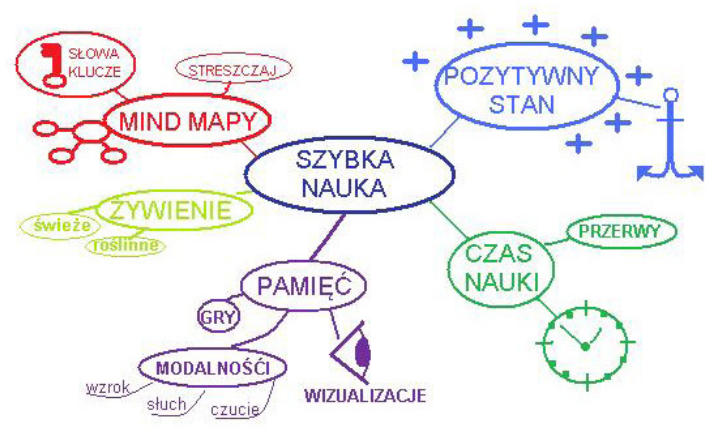

Rys. 3. Przykład mapy myśli

Źródło: http://www.projektsukces.pl/mindmaps.html (Mindmaps, b.d.)

Do zasobów słów kluczowych/tagów można próbować zastosować prawo Pareto: 80/20. Zasada 80/20 mówi, że w zbiorowości niejednorodnej 20\% elementów reprezentuje 80\% skumulowanej wartości cechy, która służy jako kryterium klasyfikacji. Odnosząc to prawo do przedmiotu naszych rozważań, można zakładać, że $20 \%$ słów kluczowych stanowi słownictwo podstawowe danego języka słów kluczowych. Pozostałe $80 \%$ to słownictwo pomocnicze.

\section{Co dalej ze słowami kluczowymi i tagami?}

Co do przyszłości słów kluczowych i tagów istnieje wiele opinii entuzjastycznych oraz pesymistycznych. Pierwsze opierają się na przekonaniu, że języki słów kluczowych czeka świetlana przyszłość. Pesymiści dostrzegają już koniec języków słów kluczowych. Zbiorowa inteligencja jest w stanie rozwiązać wszystkie problemy (Bojar, 2009). Potrzeba więc tzw. złotego środka, który gwarantuje w teorii i praktyce języków informacyjno-wyszukiwawczych 
jednoczesne współistnienie dwóch paradygmatów: taksonomicznego i folksonomicznego. Słowa kluczowe/języki słów kluczowych podlegają ewolucji i nadal będą podlegać gruntownym zmianom, przy czym będzie to przede wszystkim dopasowywanie się do możliwości ludzkiego umysłu, stąd tendencja do przesuwania się ich interpretacji w stronę języka naturalnego. Kiedy zastanawiamy się nad dalszymi losami tych jednostek leksykalnych, niewątpliwie $\mathrm{w}$ polu naszego widzenia pojawiają się folksonomie, ontologie i mapy myśli jako nowy rodzaj struktur słów kluczowych i tagów.

Kierunki dalszych prac badawczych to m.in. próba wykorzystania teorii przestrzeni mentalnych i integracji pojęciowej (Libura, 2010), ujęcie kognitywne słów kluczowych, semantyzacja leksyki języków słów kluczowych i jej wykorzystanie w tezaurusach, ontologiach, mapach myśli. To właśnie z teorii przestrzeni mentalnych i integracji pojęciowej może płynąć pewna inspiracja do dalszych badań nad słowami kluczowymi. Teoria ta opiera się na założeniu, że wyrażenia językowe nie posiadają stałego sensu, a jedynie pewien potencjał znaczenia, który może być i jest wykorzystywany oraz prezentowany na różne sposoby za pomocą słów kluczowych i dynamicznych powiązań między nimi. To inspiracja płynąca ze współczesnej myśli językoznawczej. Można przypuszczać, a nawet być pewnym, że w nieodległej przyszłości zniknie bariera terminologiczna między słowami kluczowymi a tagami, polegająca na tym, że termin słowo kluczowe stosuje się do rzeczywistości nieelektronicznej, tagi zaś - do sfery elektronicznej. Sfera elektroniczna będzie bowiem stopniowo eliminować rzeczywistość tradycyjną i stawać się dominującą (Woźniak-Kasperek, 2010). W związku z tym słowa kluczowe będą „zanikać”, a tagi przybierać na sile semantycznej.

\section{Podsumowanie}

Do niedawna systemy wyszukiwania informacji były budowane na zasadzie, że to użytkownik (umysł ludzki) powinien dopasować się do systemu wyszukiwania informacji. Obecnie mamy do czynienia z tendencją odwrotną. Buduje się systemy dostosowane do możliwości ludzkiego mózgu (Malak, 2012). Stąd potrzeba semantyzacji leksyki języków informacyjno-wyszukiwawczych, w tym słów kluczowych i tagów. Pole semantyczne języków słów kluczowych jest bardziej lub mniej płaskie. Podobnie jak każdy kij ma dwa końce, tak i języki/słowa kluczowe mają zalety oraz wady, a słowa kluczowe to 
niehomogeniczna grupa słownictwa zarówno pod względem strukturalnym, jak i funkcjonalnym. Podobnie jest $\mathrm{z}$ tagami.

Stale należy mieć na uwadze, że słowa kluczowe i tagi to w praktyce słownictwo swoistego rodzaju ,języków”, które - podobnie jak język naturalny - podlegają ciągłym przemianom, stąd potrzeba ciągłego uwzględniania aktualnego słownictwa danego języka naturalnego oraz najnowszych osiągnięć badań językoznawczych, a także ciągłego nadążania za praktyką (pragmatyką) stosowania słów kluczowych i tagów. Słowa kluczowe i tagi są nie tylko stosunkowo łatwymi językowymi narzędziami wymiany informacji, lecz także cenną bazą danych/informacji i nieocenionym źródłem informacji o zagadnieniach będących przedmiotem tej wymiany. Dalsze badania nad słowami kluczowymi powinny w większym stopniu uwzględniać najnowsze osiągnięcia psychologii, socjologii, kognitywistyki oraz językoznawstwa.

Prace nad słowami kluczowymi stanowią krok w kierunku budowy lingwistycznych narzędzi do semantyzacji środowiska wyszukiwawczego w Internecie. Przyszłość wyszukiwarek zależy bowiem od jakości narzędzi „sense making”, w tym od języków informacyjno-wyszukiwawczych, gdyż jakość systemu wyszukiwawczego opiera się na sile semantycznej języka użytego do tworzenia i wyszukiwania metadanych oraz na jakości jego wizualizacji (Górska, 2012). Zdaniem Anny Górskiej na podstawie obserwacji tendencji rozwoju obecnie stosowanych języków informacyjno-wyszukiwawczych można zaryzykować prognozę rozwoju folksonomii w kierunku tezaurusów (Górska, 2012). Kontynuowanie prac nad wspomnianymi strukturami, a także wykazanie ich realnej i potencjalnej użyteczności to kolejne kroki w pracach nad budowaniem bardzo przydatnych struktur użytecznych w wykorzystaniu języka naturalnego w opisie i wyszukiwaniu informacji. Przytoczone wnioski i zasygnalizowane kierunki badań świadczą o tym, że prowadzone prace nad słowami kluczowymi i tagami na potrzeby bibliografii slawistycznej mają mocne uzasadnienie.

\section{Bibliografia}

BabelNet. (b.d.). W Wikipedia, wolna encyklopedia. Pobrano 30 grudnia 2013, z http://en.wikipedia. org/wiki/BabelNet

Babik, W. (2010). Słowa kluczowe. Kraków: Wydawnictwo Uniwersytetu Jagiellońskiego. 
Bojar, B. (2002), Słownik encyklopedyczny informacji, języków i systemów informacyjno-wyszukiwawczych. Warszawa: Wydawnictwo Stowarzyszenia Bibliotekarzy Polskich.

Bojar, B. (2009). Języki informacyjno-wyszukiwawcze wczoraj, dziś... czy jutro. Zagadnienia Informacji Naukowej, 1(93), 3-24.

Czapik, G., Gruszka, Z., \& Tadeusiewicz, H. (2011). Podręczny słownik bibliotekarza (1. wyd.). Warszawa: Wydawnictwo Stowarzyszenia Bibliotekarzy Polskich.

Efektowna wizualizacja pojęć - chmura tagów. (b.d.). Pobrano 30 grudnia 2013, z http:// praktykatrenera.pl/efektowna-wizualizacja-pojec-chmura-tagow

Folksonomia. (b.d.). W Wikipedia, wolna encyklopedia. Pobrano 30 grudnia 2013, z http:// pl.wikipedia.org/wiki/Folksonomia

Furner, J. (2010). Folksonomies. W M. J. Bates \& M. Niles Maack, Encyclopedia of Library and Information Science. (3. wyd., ss. 1856-1866). Boca Raton (FL): CRC Press.

Górska, A. (2012). Tagowanie kontrolowane - oksymoron czy przyszłość języków informacyjno-wyszukiwawczych? Zagadnienia Informacji Naukowej, 2(100), 6-17.

Libura, A. (2010). Teoria przestrzeni mentalnych i integracji pojęciowej. Struktura modelu i jego funkcjonalność. Wrocław: Wydawnictwo Uniwersytetu Wrocławskiego.

Malak, P. (2012). Indeksowanie treści. Porównanie metod tradycyjnych i automatycznych. Warszawa: Wydawnictwo Stowarzyszenia Bibliotekarzy Polskich.

Migoń, K. (2008). O współczesnej sytuacji badawczej w naukach o książce, bibliotece i informacji. Przegląd Biblioteczny, 76(1), 14-21.

Mindmaps. (b.d.). Pobrano 30 grudnia 2013, z http://www.projektsukces.pl/mindmaps.html

Noruzi, A. (2006). Folksonomies: (Un)controlled Vocabulary? Knowledge Organization, 33(4), 199-203.

Roszkowski, M. (b.d.). Tagowanie, folksonomie i systemy organizacji wiedzy. Pobrano 30 grudnia 2013, z http://www.slideshare.net/rosz_mar/tagowanie-folksonomie-i-systemyorganizacji-wiedzy

Smiraglia, R. P. (2013). Keywords, Indexing, Text Analysis: An Editorial. Knowledge Organization, (3), 155-159.

Stępień, K. (2010). Folksonomie, czyli społecznościowe opisywanie treści. Warszawa: Wydawnictwo Stowarzyszenia Bibliotekarzy Polskich.

Woźniak-Kasperek, J. (2010). Języki informacyjne: między tradycją a nadzieją na cyfrową przyszłość. Przegląd Biblioteczny, (1), 5-17.

Woźniak-Kasperek, J. (2011). Wiedza i język informacyjny w paradygmacie sieciowym. Warszawa: Wydawnictwo Stowarzyszenia Bibliotekarzy Polskich.

Zaremba, M. (2011). Odpowiedni dać rzeczy ... tag. Folksonomia jako uniwersalny model klasyfikacji treści w Internecie. Media i Społeczeństwo, (1), 112-119. 


\section{Keywords, tags... and what else?}

\section{Summary}

Keywords and their latest versions, called tags, are the object of this paper. Those expressions are treated as elements of the lexical systems of respective languages: the keyword language and the tag language. Our presentation of those vocabulary groups is intended to demonstrate that they are not homonymous, in structural or functional respects. Those two lexical resources are presented rather from the viewpoint of the theory of indexing and retrieval languages as well as the information search theories.

Considering the future of the languages in question, the author presents the folksonomies and the possibilities of application of the respective vocabulary collections in the construction of tools required for semantization of the information retrieval environment in the Internet, including the construction of ontology and thought maps.

Special attention was paid to the idea that keywords and tags are practically equivalent to specific "languages" which, similarly to natural languages, are subjected to continuous changes. For that reason, it is necessary to regularly monitor them and consider their practical application in document and information description and search.

The works on keywords constitute a step towards the construction of linguistic tools for the needs of a semantic website. This paper is a contribution to the discussion on the development of keyword vocabularies created at the Institute of Slavic Studies of the Polish Academy of Sciences in Warsaw. Such vocabularies constitute part of the Slavic bibliographic information system.

Keywords: folksonomy; keywords; natural language; ontology; tagging; tags; tag cloud

Słowa kluczowe: chmura tagów; folksonomie; język naturalny; ontologia; słowa kluczowe; tagi; tagowanie 